\title{
Urinary C-Peptide Tracks Seasonal and Individual Variation in Energy Balance in Wild Chimpanzees
}

\section{Citation}

Thompson, Melissa Emery, Martin N. Muller, Richard W. Wrangham, Jeremiah S. Lwanga, and Kevin B. Potts. 2009. Urinary C-peptide tracks seasonal and individual variation in energy balance in wild chimpanzees. Hormones and Behavior 55(2): 299-305.

\section{Published Version}

doi:10.1016/j.yhbeh.2008.11.005

\section{Permanent link}

http://nrs.harvard.edu/urn-3:HUL.InstRepos:3693702

\section{Terms of Use}

This article was downloaded from Harvard University's DASH repository, and is made available under the terms and conditions applicable to Other Posted Material, as set forth at http:// nrs.harvard.edu/urn-3:HUL.InstRepos:dash.current.terms-of-use\#LAA

\section{Share Your Story}

The Harvard community has made this article openly available.

Please share how this access benefits you. Submit a story.

Accessibility 


\title{
Urinary C-peptide tracks seasonal and individual variation in energy balance in wild chimpanzees
}

\author{
Melissa Emery Thompson ${ }^{\mathrm{a}, \mathrm{b}, *}$, Martin N. Muller ${ }^{\mathrm{a}}$, Richard W. Wrangham ${ }^{\mathrm{b}}$, \\ Jeremiah S. Lwanga ${ }^{c}$, Kevin B. Potts ${ }^{\mathrm{d}}$ \\ a Department of Anthropology, University of New Mexico, Albuquerque, NM 87131, USA \\ b Department of Anthropology, Harvard University, Cambridge, MA 02138, USA \\ c Makerere University Biological Field Station, PO Box 409, Fort Portal, Uganda \\ d Department of Anthropology, Yale University, New Haven, CT 06511, USA
}

\section{A R T I C L E I N F O}

\section{Article history:}

Received 6 October 2008

Revised 11 November 2008

Accepted 12 November 2008

Available online $\mathrm{xxxx}$

\section{Keywords:}

Energetics

Insulin

Dietary quality

Endocrinology

Dominance rank

Immune function

Nutrition

Seasonality

\begin{abstract}
A B S T R A C T
C-peptide of insulin presents a promising new tool for behavioral ecologists that allows for regular, noninvasive assessment of energetic condition in wild animals. C-peptide is produced on an equimolar basis with insulin, thus is indicative of the body's response to available glucose and, with repeated measurement, provides a biomarker of energy balance. As yet, few studies have validated the efficacy of C-peptide for monitoring energy balance in wild animals. Here, we assess seasonal and interindividual variation in urinary C-peptide concentrations of East African chimpanzees (Pan troglodytes schweinfurthii). We assayed 519 urine samples from 13 adult male chimpanzees in the Kanyawara community of Kibale National Park, Uganda. Cpeptide levels were significantly predicted by the total amount of fruit and the amount of preferred fruit in the diet. However, chimpanzees had very low C-peptide titers during an epidemic of severe respiratory illness, despite highly favorable feeding conditions. Kanyawara males had significantly lower C-peptide levels than males at Ngogo, a nearby chimpanzee community occupying a more productive habitat. Among Kanyawara males, low-ranking males had consistently higher C-peptide levels than dominant males. While counterintuitive, this result supports previous findings of costs associated with dominance in male chimpanzees. Our preliminary investigations demonstrate that C-peptide has wide applications in field research, providing an accessible tool for evaluating seasonal and individual variation in energetic condition, as well as the costs of processes such as immune function and reproduction.
\end{abstract}

(C) 2008 Elsevier Inc. All rights reserved.

\section{Introduction}

Quantifying the energetic status of animals in the wild is essential for behavioral ecologists studying the effects of environmental variation on energy budgets, social behavior and reproduction. However, accurately and consistently collecting such data in the field is a considerable challenge, particularly for species that cannot be easily trapped or weighed, or those exhibiting broad dietary diversity and unpredictable food availability. Chimpanzees, like many primate species, present both difficulties. Chimpanzee diets are highly varied, even over short time periods, and individual food species vary widely in their nutritional value (Conklin-Brittain et al., 1998, 2006; Emery Thompson and Wrangham, 2008). Individuals show significant variation in both energetic expenditure and access to particular food resources (Emery Thompson et al., 2007; Murray et al., 2006; Pontzer and Wrangham, 2006), while large group size and flexible social

\footnotetext{
* Corresponding author. Department of Anthropology, MSC01-1040, University of New Mexico, Albuquerque, NM 87131, USA. Fax: +1 5052770874.

E-mail address: memery@unm.edu (M. Emery Thompson).
}

organization preclude the estimation of caloric intake and expenditure of multiple individuals on a regular basis. Finally, although weights have been obtained from some field sites (Pusey et al., 2005; Uehara and Nishida, 1987), this normally requires provisioning, which disrupts natural feeding and ranging behavior.

Recent research suggests that C-peptide of insulin may provide a more direct tool for assessing relative energetic condition in primates. Insulin is the key hormone regulating intermediary metabolism; it coordinates the uptake and storage of glucose, and provides an integrated signal of energy balance to the brain (Norman and Litwack, 1997; Schwartz et al., 1992; Strack et al., 1995). When insulin is produced from proinsulin in the pancreas, the C-peptide molecule is cleaved off and released into the bloodstream on an equimolar basis (Melani et al., 1970; Rubenstein et al., 1969). Unlike insulin, C-peptide does not undergo significant clearance by the liver, meaning that it is probably a better indicator of pancreatic insulin secretion than circulating insulin itself (Polonsky et al., 1986). Furthermore, C-peptide can be measured in urine, and urinary concentrations correlate with those in serum (Gjessing et al., 1989; Kruszynska et al., 1987; Meistas et al., 1982). This has recently been demonstrated for chimpanzees 
specifically (Sherry and Ellison, 2007). In addition to being noninvasive, urine sampling for hormones has the advantage that it provides a measurement over a longer period of hormonal release than in blood, evening out transient fluctuations (Whitten et al., 1998).

While C-peptide is typically used for clinical diagnosis of insulin resistance and other metabolic disorders, recent studies demonstrate that it can also be used to quantify relative energy balance. Ellison and Valeggia (2003) employed urinary C-peptide measures to track longitudinal changes in energy balance during the postpartum period in human females, tying resumption of cycling to C-peptide thresholds. In the laboratory, Deschner et al. (2008) found that C-peptide levels correlated with body mass changes during a 2-week period of caloric restriction, as well as during the subsequent period of recovery. Emery Thompson and Knott (2008) found strong significant correlations of C-peptide with both ripe fruit availability and caloric intake estimates for orangutans in the wild. For chimpanzees, Sherry and Ellison (2007) reported that well-fed captive subjects had significantly elevated C-peptide titers compared with wild subjects. Using a preliminary sample of 25 urine specimens from male chimpanzees in our community at Kanyawara, Kibale National Park, Uganda, they also suggested that C-peptide levels could distinguish fruit-poor from fruit-rich periods, and that dominant males were in better energetic condition than subordinates. This laid the groundwork for the present investigation, in which we use a much larger data set from the same community to further validate the efficacy of C-peptide for tracking changes in energy balance within and between individuals, and to provide a stronger test of the hypothesis that male dominance rank is associated with energy balance in chimpanzees.

This study has three major objectives. First, we examine the relationship of dietary quality to average C-peptide levels of male chimpanzees. Following previous work on the nutritional ecology of this chimpanzee community (Conklin-Brittain et al., 1998, 2006; Emery Thompson and Wrangham, 2008), we test both the effects of variation in fruit content of the diet and the effects of specific preferred (drupe) fruits. Second, we test whether C-peptide can adequately capture individual variation in energy balance by comparing Kanyawara chimpanzees with those in a nearby group inhabiting a richer habitat. Finally, we examine whether variation in male social status has an impact on energy balance, as reflected in Cpeptide levels. There is a general expectation that high-ranking males should have increased access to energy, because they tend to occupy prime feeding sites and monopolize high-quality foods such as meat (Muller and Mitani, 2005). However, high-ranking males also exhibit elevated aggression rates and stress hormone levels, suggesting that they invest disproportionately in behaviors that are energetically costly, potentially negating their nutritional advantage (Muller and Wrangham, 2004a,b).

\section{Materials and methods}

\section{Study site}

Our primary research focus was the Kanyawara community of chimpanzees in the Kibale National Park, Uganda. The Kanyawara chimpanzees' home range spans approximately $38 \mathrm{~km}^{2}$ (Wilson, 2001) of moist deciduous forest containing areas of swamp, grassland, and colonizing forest (Chapman and Wrangham, 1993). The community has been under continuous observation since 1987, and has been fully habituated to human observers since approximately 1994. Data for this study were collected between 1998 and 2005, during which time the chimpanzee community numbered $41-52$ individuals, including 10-11 adult males ( $\geq 15$ years). Male ranks are assigned annually, based on the direction of pant-grunt vocalizations (a formal signal of subordinance) and the outcome of decided dyadic agonistic bouts (ranks used in Kahlenberg, 2006; Muller, 2002; Muller et al., 2007).

\section{Feeding data}

Kibale Chimpanzee Project staff, including long-term field assistants, the study authors, and other visiting researchers and students, conduct daily observations of the Kanyawara community, following one chimpanzee party from nest to nest when possible. These observations include recording the feeding behavior of the chimpanzee party (if feeding, and what species and plant part) every $15 \mathrm{~min}$. Chimpanzee parties typically occupy a single food patch, particularly when feeding on fruits; thus it is rare for individuals in the party to be consuming different food items. When this occurs, the food being consumed by the majority of individuals is recorded, or we use a broader classification (e.g., "piths" instead of Acanthus pubescens pith).

We determined the composition of the chimpanzee diet on a monthly basis by calculating the number of scans in which a particular food was consumed as a percentage of total feeding observations. We determined two separate dietary quality variables: \% of fruit and \% drupe fruit. Following previous studies, drupe fruits are generally preferred to figs by chimpanzees in this population, and they have strong effects on female reproductive function (Emery Thompson and Wrangham, 2008; Wrangham et al., 1996).

We selected 28 months (occurring between Jun 1998 and Aug 2005) that had adequate urine sampling of multiple adult males and represented a range of feeding conditions. These study months grouped into 15 "seasons" (see also Emery Thompson and Wrangham, 2008; Gilby and Wrangham, 2007), comprised of a month or group of consecutive months with similar dietary characteristics (Table 1). Seasons were categorized as one of the following: (a) low fruit consumption: fruits $<50 \%$ of $\operatorname{diet}(N=4)$, (b) average fruit consumption:

Table 1

Dietary and sampling characteristics by season

\begin{tabular}{|c|c|c|c|c|c|c|c|c|}
\hline Season type & Months & $\begin{array}{l}\text { All fruit } \\
\text { (\% of diet) }\end{array}$ & $\begin{array}{l}\text { Figs } \\
\text { (\% of diet) }\end{array}$ & $\begin{array}{l}\text { Drupes } \\
\text { (\% of diet) }\end{array}$ & $\begin{array}{l}\text { Leaves }+ \text { piths } \\
\text { (\% of diet) }\end{array}$ & Dominant fruit species & $N$ males sampled & $N$ samples \\
\hline \multirow[t]{3}{*}{ Preferred fruit } & Dec 1998 & 76.9 & 3.5 & 73.4 & 18.0 & Uvariopsis congensis & 8 & 27 \\
\hline & Nov 1999-Jan 2000 & 80.5 & 3.2 & 77.3 & 17.5 & Mimusops bagshawei & 9 & 27 \\
\hline & Jul-Aug 2000 & 84.0 & 6.9 & 77.1 & 15.1 & $U$. congensis & 8 & 54 \\
\hline Preferred fruit + disease outbreak & Mar-Apr 2001 & 75.6 & 3.3 & 72.3 & 23.3 & M. bagshawei & 7 & 39 \\
\hline \multirow[t]{4}{*}{ High fruit } & Apr-May 1999 & 70.1 & 65.6 & 4.4 & 29.1 & Ficus natalensis, F. sansibarica & 7 & 33 \\
\hline & May 2002 & 72.0 & 56.1 & 15.9 & 28.0 & F. exasperata & 3 & 7 \\
\hline & Jan-Feb 2004 & 74.2 & 59.3 & 14.8 & 25.8 & F. sur, F. sansibarica & 6 & 20 \\
\hline & Jan-Feb 2005 & 76.5 & 52.7 & 3.0 & 63.5 & F. natalensis & 9 & 53 \\
\hline \multirow[t]{3}{*}{ Average fruit } & Dec 2000 & 64.4 & 62.2 & 2.2 & 35.7 & & 2 & 5 \\
\hline & Sep-Oct 2001 & 62.1 & 37.0 & 25.1 & 37.5 & & 8 & 29 \\
\hline & Jun 2003 & 57.2 & 38.8 & 18.5 & 40.6 & & 5 & 13 \\
\hline \multirow[t]{4}{*}{ Low fruit } & Jun-Oct 1998 & 32.6 & 29.4 & 3.2 & 58.2 & & 11 & 138 \\
\hline & Jul-Aug 1999 & 46.6 & 42.7 & 3.8 & 52.0 & & 7 & 37 \\
\hline & Aug 2004 & 47.2 & 30.7 & 16.5 & 52.3 & & 8 & 39 \\
\hline & Aug 2005 & 35.8 & 32.8 & 3.0 & 63.5 & & 5 & 13 \\
\hline
\end{tabular}


fruits $50-70 \%$ of $\operatorname{diet}(N=3)$, (c) high fruit consumption: fruits $>70 \%$ of diet $(N=4)$ with low drupe fruit component, or (d) preferred fruit consumption: total fruit consumption was high $(>70 \%)$ and a single drupe species accounted for $40 \%$ of feeding time $(N=4)$. The latter category included 2 seasons each of Mimusops bagshawei and Uvariopsis congensis. These species, which have rare but productive fruiting peaks, are the two most preferred species at Kanyawara, as judged by feeding intensity in relation to availability (Emery Thompson and Wrangham, 2008; Wrangham et al., 1996). To control for carryover effects from previous months, we selected seasons that were preceded by months of average fruit consumption; thus, for the "average" fruit seasons in the analysis, we considered only samples collected from the second and subsequent months of average fruit consumption.

To test whether urinary C-peptide was a valid indicator of wild chimpanzee energetic condition, we assessed mean C-peptide titers of adult male chimpanzees in each season. The dataset included 519 samples from 13 adult males (mean $=40$, range 5-99 samples $/$ male depending on number of seasons while alive and adult). Because female reproductive state is expected to significantly influence her energy balance, and the extent of this influence is not yet understood, we examined only adult males for this study.

\section{Urine collection and C-peptide analysis}

Urine samples were collected during daily chimpanzee observations. We attempted to collect first-morning voids from nested individuals and then sampled opportunistically throughout the day. Samples were periodically tested in the field laboratory for health indicators using Chemstrip urinalysis dipsticks (Roche-Diagnostics, see also Kelly et al., 2004). Samples were frozen on the day of collection and transported on ice to the Primate Reproductive Ecology Laboratory at Harvard University (see also Emery Thompson, 2005a; Muller \& Wrangham, 2004a,b).

C-peptide of insulin was assayed with a commercial radioimmunoassay kit (DSL-7000, Diagnostic Systems Laboratories, Webster, TX; see also Ellison and Valeggia, 2003; Emery Thompson and Knott, 2008; Sherry and Ellison, 2007), following the manufacturer's overnight protocol with the exception that samples were assayed at full concentration (1:1) to maximize recoveries within the range of the standard curve. Interassay $(N=13)$ and intraassay coefficients of variation were $8 \%$ and $12 \%$, respectively. Assay sensitivity was approximately $0.01 \mathrm{ng} / \mathrm{ml}$. We standardized all urinary C-peptide measurements for creatinine $(\mathrm{Cr})$, and we discarded samples with creatinine concentrations $<0.01 \mathrm{mg} / \mathrm{ml}$.

Testosterone and cortisol excretion in chimpanzee urine show a clear diurnal pattern, with elevated levels in the early morning followed by a steady decline through the day (Muller and Lipson, 2003). However, Deschner et al. (2008) found no significant circadian effects on C-peptide titers in bonobo urine. We similarly found no circadian effects in our urinary C-peptide results, as means of individual male means calculated for each of 14 intervals (0500$1800)$ showed no relationship with time of day $\left(R^{2}=0.095\right.$, $d f=14$ hour-blocks, $p=0.27$ ). Consequently, C-peptide values were not corrected for time of sample collection.

\section{Comparative data}

To determine whether C-peptide levels can reflect differences in energy balance between individuals, we compared our sample from Kanyawara with samples collected from adult males in the nearby Ngogo community of chimpanzees. While only separated by approximately $10 \mathrm{~km}$ (Chapman et al., 1999), the home ranges of these two communities differ markedly in their ecological productivity.

The habitat difference between Kanyawara and Ngogo is supported by multiple data sources. First, chimpanzee densities, a reflection of fruit tree densities (Balcomb et al., 2000) are higher at Ngogo than at
Kanyawara. Specifically, density at Kanyawara was estimated at 1.4 chimpanzees $/ \mathrm{km}^{2}$ in 1996-1998 (calculated from Wilson 2001). This is lower than the estimated average density of 2.3 chimpanzees $/ \mathrm{km}^{2}$ for Kibale forest as a whole (Plumptre et al., 2003) and that for Ngogo specifically (5-6 chimpanzees $/ \mathrm{km}^{2}$, calculated from community and range sizes reported in Mitani, 2006; Watts and Mitani, 2002). Second, in surveys conducted during the 1990s, the average monthly density of trees bearing ripe fruit at Ngogo (1748 trees $/ \mathrm{km}^{2}$ ) substantially exceeded that at Kanyawara (878 trees/ $/ \mathrm{km}^{2}$, Chapman et al., 1999).

Recent surveys of the two habitats, incorporating nutritional biochemistry, confirmed the conclusion that Ngogo chimpanzees have higher net caloric gain than Kanyawara chimpanzees over various temporal scales. Specifically, average daily and monthly net caloric gain rates, which have been shown to reflect fitness indices in other species (e.g., zebra finches (Taeniopygia guttata), Lemon, 1991), were higher among Ngogo chimpanzees, and these values were significantly less variable over time than at Kanyawara (Potts, 2008). These differences in foraging efficiency are likely attributable to three primary factors. First, high-quality fruit sources, including the most common dietary items (those constituting $75-80 \%$ of the diet), are significantly more abundant at Ngogo than at Kanyawara. Second, plant species characterized by inter-individual synchrony in fruit production during times of habitat-wide fruit scarcity (e.g., Pterygota mildbraedii) occur at an unusually high density at Ngogo, and this provides temporal stability to the resource base of Ngogo chimpanzees relative to Kanyawara chimpanzees. Third, several of the most nutritious fruit resources at Ngogo, in terms of lipids, protein, and digestible energy (e.g., Chrysophyllum albidum, Ficus mucuso), are plentiful there but uncommonly found at Kanyawara (Potts, 2008).

We assayed C-peptide in 122 urine samples collected from adult males at Ngogo. Collection and analysis protocols were identical to those from Kanyawara. Though we were unable to assay as many samples as for Kanyawara, we wanted to capture as much of the range of annual and individual variation as possible to make a valid comparison. Thus, we selected 3-7 samples (mean=4.5) collected from each of 27 adult males between August 2004 and June 2005 (mean $=11.8$ total samples per month). We made every effort to spread each male's samples across the study period, with no two samples collected in a single month from a single male.

\section{Data analysis}

We calculated an average C-peptide level for each male in each season. To test for variation in relation to dietary quality, we standardized each male's seasonal average by calculating a $z$-score in relation to his overall mean and standard deviation. We used linear regressions to compare the average standardized C-peptide in each season in relation to dietary characteristics.

For intercommunity comparisons, we averaged C-peptide concentrations (ng/mg-Cr) for each male across all study months and compared the set of male averages between communities with a Mann-Whitney $U$-test.

For tests of the effects of dominance rank on C-peptide, we determined the $\mathrm{C}$-peptide level of the male at each ordinal rank for each season. In other words, we accounted for changes in the dominance hierarchy over the 8 years of study rather than using a male's average rank over the study period. Because factors such as mating success, paternity outcomes, and aggressive behavior all decline precipitously with rank in chimpanzees (Boesch et al., 2006; Constable et al., 2001; Duffy et al., 2007; Muller and Wrangham, 2004a), we considered the top 4 ranking males in any year to be "high-ranking" and the remaining adults to be "low-ranking" in our categorical analysis. In order to control for fluctuating food availability, we conducted a Wilcoxon signed-ranks test, matching high and low-ranking males in each season. To make sure this analysis did not mask variation within categories, such as that between the alpha male and other high-ranking 
males, we also averaged C-peptide concentrations across seasons for each ordinal rank and then calculated a linear regression.

\section{Results}

\section{C-peptide and fluctuating diet at Kanyawara}

There was a significant positive relationship between the average C-peptide of adult males and the percentage of ripe fruit in the diet (by month: $R^{2}=0.272, d f=27, p=0.004$; by season: $R^{2}=0.271, d f=14$, $p=0.046$, Fig. 1). While this finding supports the use of C-peptide as a measure relative energy balance, a large proportion of variance in Cpeptide was unexplained. Two considerations may help explain additional variation in the dataset. First, variation in energy expenditure should also impact energy balance and C-peptide concentrations. Second, while the percentage of fruit in the diet, as an index of habitat productivity, provides a broad gauge of energy intake, additional variation in the nutritional quality of fruit eaten should impact energy balance.

We did not have any standard detailed measures of energetic expenditure over the entire study period. However, the effects of one critical energetic cost, immune defense, produced a large effect in our dataset. Whereas in most months fewer than 5 individuals are observed with mild symptoms of disease (coughing, sneezing, runny nose, diarrhea), 19 of 22 individuals observed during March 2001 had symptoms of severe respiratory illness, usually on multiple observation days. The deaths of two adult females during that month were directly attributed to the outbreak. Four additional individuals ( 1 adult male, 1 adult female and her 2 dependent offspring) also disappeared at the same time, though we did not observe them with symptoms prior to their disappearance. The five adult males we obtained urine from in March 2001 had respiratory symptoms, and each also had leukocytes in his urine, indicating the presence of infection. Though symptoms subsided, all 7 males we sampled also tested positive for leukocytes in April. Most males also tested positive for blood and nitrites in the urine, further indicating infection. Fruit consumption, however, was well above average (76.7\% and $74.1 \%$ ) in March-April 2001, and fruits consumed were almost entirely (>90\%) drupe fruits, as the illness coincided with the fruiting peak of $M$. bagshawei (the most highly preferred food at Kanyawara).

Despite very favorable feeding conditions, male C-peptide levels during the respiratory outbreak were the among the lowest of any months we studied (open squares in Fig. 1). When we removed this season from our analysis, we found a much stronger predictive

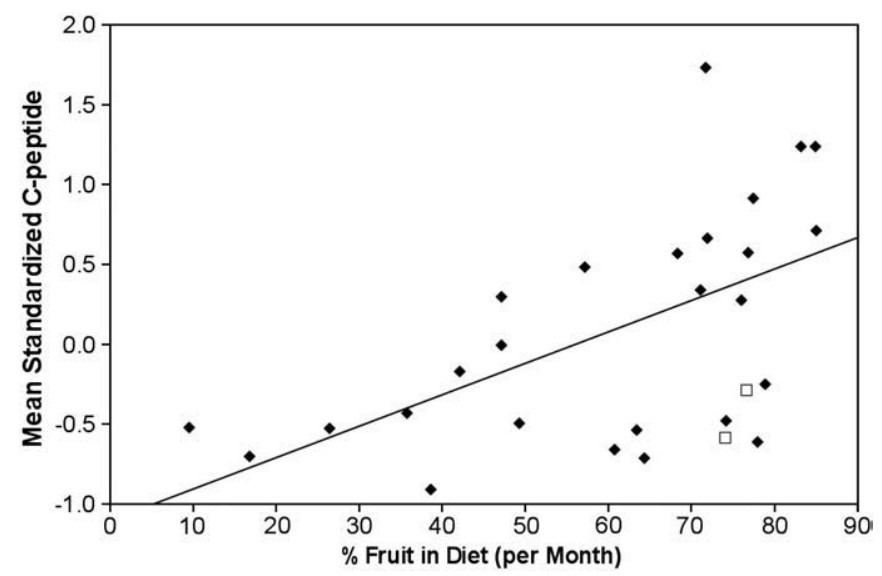

Fig. 1. Ripe fruit consumption (\% of diet) predicts mean C-peptide concentrations of Kanyawara chimpanzee males. Each point represents the mean of males sampled per month after standardization for individual variation. The months represented by open squares (March-April 2001) coincided with severe respiratory illness affecting most Kanyawara chimpanzees. These points are not included in the best-fit line displayed.

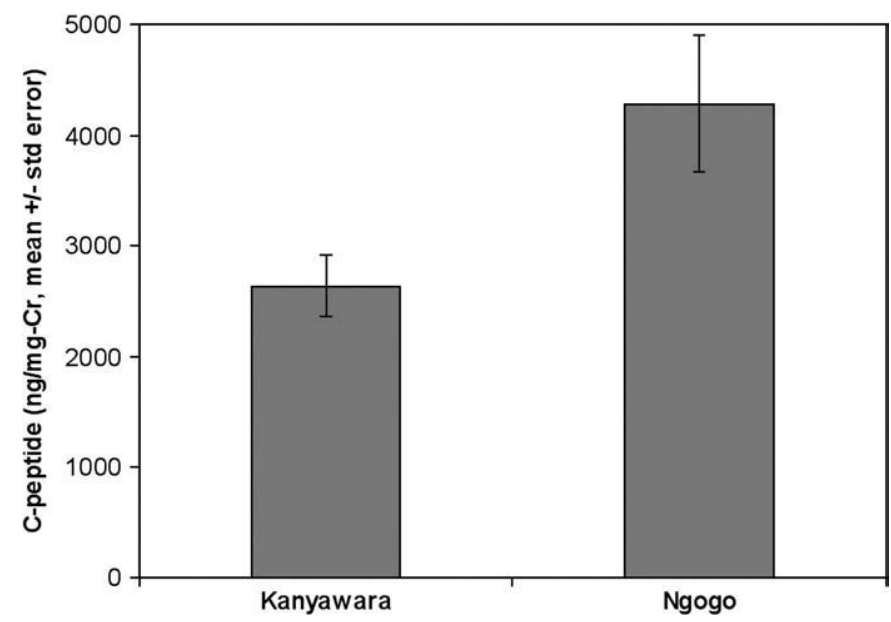

Fig. 2. C-peptide concentrations in adult male Kanyawara chimpanzees are significantly lower than in males of the nearby Ngogo community, which inhabits a higher-quality home range.

relationship between fruit consumption and C-peptide (by month: $R^{2}=0.337, d f=25, p=0.002$; by season: $\left.R^{2}=0.387, d f=13, p=0.018\right)$. In all further analyses, we excluded this season of severe epidemic.

Because Kanyawara chimpanzees generally prefer drupe fruits to the figs available in this habitat, and because behavioral and reproductive outcomes have been linked to consumption of drupe fruits specifically, we expected that drupe fruit consumption would be a better predictor of $\mathrm{C}$-peptide than fig fruit consumption. Indeed, the percentage of drupe fruit in the diet was positively related to Cpeptide concentrations (by month: $R^{2}=0.155, d f=25, p=0.047$; by season: $\left.R^{2}=0.198, d f=13, p=0.11\right)$, whereas the percentage of figs in the diet had no predictive value (by month: $R^{2}=0.001, d f=25, p=0.86$; by season: $\left.R^{2}=0.004, d f=25, p=0.83\right)$. We should note, however, that the single highest $C$-peptide average was obtained, not during a drupe season, but during a month dominated by consumption of Ficus sur.

\section{Intercommunity comparison}

To examine the potential for C-peptide to assess individual variation in energy balance, we compared the C-peptide levels of Kanyawara males to those of adult males in Ngogo, who inhabit a nearby area of higher food availability. As predicted, C-peptide levels of Ngogo males were significantly higher than those of Kanyawara males (Mann-Whitney $U, z=-3.191, N_{K}=13, N_{N}=27, p=0.001$, Fig. 2). Thus, in addition to its use in evaluating relative energetic balance of individuals over varying foraging conditions, C-peptide can robustly quantify inter-individual variation in energetic condition.

\section{Dominance rank and C-peptide levels}

Contrary to the prediction that dominance rank enhances energetic condition in males, high-ranking male chimpanzees at Kanyawara had lower C-peptide levels than lower-ranking males in 13 of 14 seasons (Wilcoxon signed-ranks test: $z=-3.233, N_{1}=N_{2}=14$, $p=0.001)$. C-peptide levels of low-ranking males were significantly higher in both seasons of high fruit availability (high fruit, drupe seasons: $z=-2.197, N=7, p=0.028$ ) and those of low to average fruit availability $(z=2.366, N=7, p=0.018)$. In fact, there was a significant negative linear relationship between ordinal rank and mean C-peptide over all seasons $\left(R^{2}=0.371, d f=10, p=0.047\right.$, Fig. 3$)$, such that the lowest ranking males had the highest $\mathrm{C}$-peptide concentrations and the alpha male had among the lowest. We found no difference in the seasonal variance in high and low-ranking male C-peptide concentrations $(F=0.988, d f=13, p=0.983)$; both experienced C-peptide 


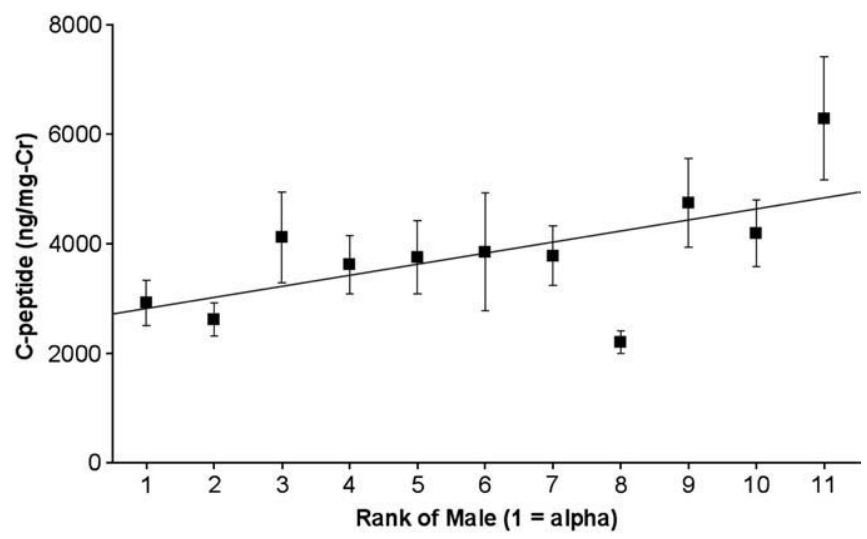

Fig. 3. C-peptide levels have a significant negative relationship with dominance rank. Markers indicate mean \pm standard error of values for each dominance rank across seasons.

increases with increasing dietary quality, though the effect was stronger for low-ranking males (high-rank: $R^{2}=0.278, d f=13$, $p=0.053$; low-rank: $R^{2}=0.380, d f=13, p=0.019$ ).

\section{Discussion}

This study joins other recent research validating the efficacy of Cpeptide for measuring energetic condition in apes (Deschner et al., 2008; Emery Thompson and Knott, 2008; Sherry and Ellison, 2007). These data provide the first thorough test of the method for chimpanzees, applying a large sample to illustrate that basic measures of dietary quality account for a substantial portion of the variation in male C-peptide concentrations. Beyond this, however, our study demonstrates various applications of the $\mathrm{C}$-peptide method, providing empirical insights about chimpanzee behavioral ecology.

First, our data illustrate that C-peptide can be used to assess the seasonal profitability of particular foods. Here, we show that drupe fruits at Kanyawara, known to be preferred by the chimpanzees, generally produced greater gains in energy balance than figs. Our data suggest that, with a broader longitudinal sample, we could quantify additional important variation within these broad categories. For instance, C-peptide concentrations of Kanyawara chimpanzees were particularly high when they consumed Ficus sur. This fig, rare at Kanyawara, produces large clusters of plump fruits and is noted as the dominant, and likely preferred, species consumed by another Ugandan chimpanzee community (Budongo: Emery Thompson, 2005b; Fawcett, 2000; Newton-Fisher, 1999; Tweheyo and Lye, 2003). While our examination focused on fruits as a category of high-quality foods, detailed, long-term C-peptide analysis could help elucidate the nutritional benefits of other items in the diverse chimpanzee diet, such as the ability of different fall-back foods to buffer seasonal fruit availability (Malenky et al., 1994). Differences in energetic benefits to the animals are not evident from the caloric content of the foods alone (for Kanyawara foods: Conklin-Brittain et al., 2006), because nutritional biochemistry cannot account for factors such as the processing time and digestibility of foods, energy expended in search effort, and spatial availability of resources. Cpeptide measurement, therefore, can complement nutritional analysis and improve the data resolution for studies of behavioral ecology that relate energetic condition to behavioral variation.

A second important application of C-peptide is for uncovering hidden energetic costs. In this study, we inadvertently included a period of serious and widespread respiratory disease and discovered that, despite superb foraging conditions, chimpanzee energy balance was severely impacted. Such data are highly valuable for understanding sources of morbidity and mortality and warrant further study, particularly as an energetic deficit like that observed here could be devastating in a period of food shortage. C-peptide also shows promise for quantifying other hidden costs, such as energy spent on growth or during gestation and lactation (Ellison and Valeggia, 2003).

A third promising application of C-peptide measures is energetic comparisons across populations. Here we show that known habitat differences between two chimpanzee home ranges in Kibale National Park are reflected in the C-peptide levels of community members. Sherry and Ellison (2007) similarly demonstrated that captive chimpanzees had higher C-peptide levels than their energeticallystressed, wild counterparts. In addition to providing a metric for energetic variation between communities, these findings demonstrate that C-peptide levels in apes reflect individual variation in energetic condition. Although habitat quality at Ngogo and Kanyawara has been assessed using directly comparable survey methods, it has generally been difficult to compare ecological productivity across chimpanzee populations. The ability to do so is essential for studies of how ecology impacts behavioral diversity. There is also potential for using relative variation in C-peptide levels to make comparisons of energy fluctuations in different species, for instance those utilizing highly seasonal food resources versus those with more consistent energy access.

Finally, C-peptide monitoring provides a convenient and finegrained means of assessing the causes of individual variation in energetic condition. Here, we examined the effect of male dominance rank on C-peptide levels, showing that contrary to expectations, lowranking males had consistently higher energy balance than highranking males over a range of ecological conditions. This contradicts the preliminary result presented for the same population in Sherry and Ellison (2007), though these authors emphasized that, having assayed only 25 samples from 4 males, their data required corroboration in a larger dataset. In the context of the current study, we cannot provide a proximate explanation for why high-ranking males do not have an energetic advantage. There are suggestions that high-ranking male chimpanzees may gain subtle feeding advantages over subordinates, such as in preferential access to prime feeding sites in a patch or enhanced ability to steal meat (Goodall, 1986; Kahlenberg, 2006; Mitani and Watts, 1999; Wrangham, 1975), though these are of arguable long-term consequence (Muller and Mitani, 2005). On the other hand, any caloric advantage of dominance may be offset by greater investment in dominance behaviors and mating competition, the energetic costs of which have not been quantified (Muller and Wrangham, 2004a,b). In other primate species, mating investment and particularly mate-guarding, a purview of dominant males, is associated with reduced time allocation to foraging (Papio sp.: Alberts et al., 1996; Packer, 1979; but see Bercovitch, 1983; Macaca fuscata: Matsubara, 2003). Previous studies of Kanyawara chimpanzees reported higher stress hormone levels in high-ranking versus lowranking males, a result which may reflect increased social stress, increased energetic stress, or both (Muller and Wrangham, 2004b). Our findings are also consistent with data from Gombe National Park, where dominance rank was not significantly correlated with body mass in male chimpanzees (Pusey et al., 2005). In that study, dominant males did, however, have lower variance in body weight, suggesting that they may have been less affected by low food availability (Pusey et al., 2005). We did not find a significant association between C-peptide variance and rank in males at Kanyawara. The alpha and beta ranks ( $\mathrm{n}$. b., the alpha was the same male throughout) did have low variance (only rank 8 was lower), but this was paired with low C-peptide levels relative to other males. On the whole, these data provide provocative reasons to pursue detailed study on tradeoffs between reproductive advantages and energetic costs in this and other species.

Insulin interacts positively with the reproductive systems of both sexes, enhancing or directly stimulating production of estradiol and progesterone by ovarian cells (Garzo and Dorrington, 1984; Greisen et al., 2001; Willis et al., 1996), testosterone by testicular cells (Pasquali et al., 1995), and prolactin by pituitary cells (Prager et al., 1988). These hormones in turn can have positive effects on insulin release 
(testosterone: Morimoto et al., 2001; prolactin: Nielsen, 1982). Thus, it is unlikely that higher testosterone levels among high-ranking chimpanzees males (Muehlenbein et al., 2004; Muller and Wrangham, 2004a) can explain their reduced C-peptide levels. The reverse may be true. It has been proposed that insulin serves as a direct signal of energetic condition within the organism and a potential mediator of energy allocation to competing physiological demands, including reproductive effort (Ellison, 2001). In addition to its use as a tool for measuring energetic condition, C-peptide assessment may also contribute significantly to our understanding of other hormonebehavior interactions in animals.

\section{Acknowledgments}

We thank the Uganda Wildlife Authority, Makerere University Biological Field Station, and the Ugandan National Council for Science and Technology for the local research support and permissions. Daily data collection for the Kibale Chimpanzee Project was performed by Francis Mugurusi, Peter Tuhairwe, Christopher Katongole, the late Christopher Muruuli, the late Donor Muhangyi, and the late John Barwogeza, and facilitated by field managers Emily Otali, Michael Wilson, Katherin Pieta, Carole Hooven, and Kimberly Duffy. We thank John Mitani and David Watts for the collaboration at Ngogo. We also thank Susan Lipson, Sonya Kahlenberg, Ross Wrangham, and Ian Gilby for their additional assistance with various parts of the study. This material is based upon work supported by the L.S.B. Leakey Foundation and the National Science Foundation under Grants 0416125, BCS-0215622 and IOB-0516644.

\section{References}

Alberts, S.C., Altmann, J., Wilson, M.L., 1996. Mate guarding constrains foraging activity of male baboons. Anim. Behav. 51,1269-1277.

Balcomb, S.R., Chapman, C.A., Wrangham, R.W., 2000. Relationship between chimpanzee (Pan troglodytes) density and large, fleshy-fruit density: conservation implications. Am. J. Primatol. 51, 197-203.

Bercovitch, F.B., 1983. Time budgets and consortships in olive baboons (Papio anubis). Folia Primatol. 41, 180-190.

Boesch, C., Kohou, G., Nene, H., Vigilant, L., 2006. Male competition and paternity in wild chimpanzees of the Tai Forest. Am. J. Phys. Anthropol. 130, 103-115.

Chapman, C.A., Wrangham, R.W., 1993. Range use of the forest chimpanzees of Kibale: implications for the understanding of chimpanzee social organization. Am. J. Primatol. 31, 263-273.

Chapman, C.A., Wrangham, R.W., Chapman, L.J., Kennard, D., Zanne, A., 1999. Fruit and flower phenology at two sites in Kibale National Park, Uganda. J. Trop. Ecol. 15, 189-211.

Conklin-Brittain, N.L., Wrangham, R.W., Hunt, K.D., 1998. Dietary response of chimpanzees and cercopithecines to seasonal variation in fruit abundance. II. Macronutrients. Int. J. Primatol. 19, 949-970.

Conklin-Brittain, N.L., Knott, C.D., Wrangham, R.W., 2006. Energy intake by wild chimpanzees and orangutans: methodological considerations and a preliminary comparison. In: Hohmann, G., Robbins, M.M., Boesch, C. (Eds.), Feeding Ecology in Apes and Other Primates. Cambridge University Press, Cambridge, MA, pp. 445-471.

Constable, J.L., Ashley, M.V., Goodall, J., Pusey, A.E., 2001. Noninvasive paternity assignment in Gombe chimpanzees. Mol. Ecol. 10, 1279-1300.

Deschner, T., Kratzsch, J., Hohmann, G., 2008. Urinary C-peptide as a method for monitoring body mass changes in captive bonobos (Pan paniscus). Horm. Behav. 54, $620-626$.

Duffy, K.G., Wrangham, R.W., Silk, J.B., 2007. Male chimpanzees exchange political support for mating opportunities. Curr. Biol. 17, 586-587.

Ellison, P.T., 2001. On Fertile Ground. Harvard University Press, Cambridge, MA.

Ellison, P.T., Valeggia, C.R., 2003. C-peptide levels and the duration of lactational amenorrhea. Fertil. Steril. 80, 1279-1280.

Emery Thompson, M., 2005a. Reproductive endocrinology of wild female chimpanzees (Pan troglodytes schweinfurthii): methodological considerations and the role of hormones in sex and conception. Am. J. Primatol. 67, 137-158.

Emery Thompson, M. 2005b. Endocrinology and ecology of wild female chimpanzee reproduction. Ph.D. dissertation. Harvard University, Cambridge, MA.

Emery Thompson, M., Kahlenberg, S.M., Gilby, I.C., Wrangham, R.W., 2007. Core area quality is associated with variance in reproductive success among female chimpanzees at Kanyawara, Kibale National Park. Anim. Behav. 73, 501-512.

Emery Thompson, M., Knott, C.D., 2008. Urinary C-peptide of insulin as a non-invasive marker of energy balance in wild orangutans. Horm. Behav. 53, 526-535.

Emery Thompson, M., Wrangham, R.W., 2008. Diet and reproductive function in wild female chimpanzees (Pan troglodytes schweinfurthii) at Kibale National Park, Uganda. Am. J. Phys. Anthropol. 135, 171-181.
Fawcett, K.A., 2000. Female relationships and food availability in a forest community of chimpanzees. Ph.D. Dissertation. University of Edinburgh, UK.

Garzo, V.G., Dorrington, J.H., 1984. Aromatase activity in human granulosa cells during follicular development and the modulation by follicle-stimulating hormone and insulin. Am. J. Obstet. Gynecol. 148, 657-662.

Gilby, I.C., Wrangham, R.W., 2007. Risk-prone hunting by chimpanzees (Pan troglodytes schweinfurthii) increases during periods of high diet quality. Behav. Ecol. Sociobiol 61, 1771-1779.

Gjessing, H., Matzen, L., Faber, O., Froland, A., 1989. Sensitivity and reproducibility of urinary C-peptide as estimate of islet B-cell function in insulin-treated diabetes. Diabet. Med. 6, 329-333.

Goodall, J., 1986. The Chimpanzees of Gombe: Patterns of Behavior. Belknap Press, Cambridge, MA.

Greisen, S., Ledet, T., Ovesen, P., 2001. Effects of androstenedione, insulin and luteinizing hormone on steroidogenesis in human granulosa luteal cells. Hum. Reprod. 16, 2061-2065.

Kahlenberg, S.M., 2006. Female-female competition and male sexual coercion in Kanyawara chimpanzees. Ph.D. Dissertation. Harvard University, Cambridge, MA.

Kelly, T., Sleeman, J., Wrangham, R.W., 2004. Urinalysis in free-living chimpanzees (Pan troglodytes schweinfurthii) in Uganda. Vet. Rec. 154, 729-730.

Kruszynska, Y., Home, P., Hanning, I., Alberti, K., 1987. Basal and 24-h C-peptide and insulin secretion rate in normal man. Diabetologia 30, 16-21.

Lemon, W.C., 1991. Fitness consequences of foraging behaviour in the zebra finch. Nature 352, 153-155.

Malenky, R.K., Kuroda, S., Vineberg, E.O., Wrangham, R.W., 1994. The significance of terrestrial herbaceous foods for bonobos, chimpanzees, and gorillas. In: Wrangham, R.W., McGrew, W.C., De Waal, F.B., Helte, P. (Eds.), Chimpanzee Cultures. Harvard University Press, Cambridge, MA, pp. 59-76.

Matsubara, M., 2003. Costs of mate guarding and opportunistic mating among wild male Japanese macaques. Int. J. Primatol. 24, 1057-1075.

Meistas, M., Rendell, M., Margolis, S., Kowarski, A., 1982. Estimation of the secretion rate of insulin from urinary excretion rate of C-peptide. Study in obese and diabetic subjects. Diabetes 31, 449-453.

Melani, F., Rubenstein, A.H., Oyer, P.E., Steiner, D.F., 1970. Identification of proinsulin and C-peptide in human serum by a specific immunoassay. Proc. Natl. Acad. Sci. 67 148-155.

Mitani, J.C., 2006. Demographic influences on the behavior of chimpanzees. Primates 47, 6-13

Mitani, J.C., Watts, D.P., 1999. Demographic influences on the hunting behavior of chimpanzees. Primates 109, 439-454.

Morimoto, S., Fernandez-Mejia, C., Romero-Navarro, G., Morales-Peza, N., Diaz-Sanchez, V., 2001. Testosterone effect on insulin content, messenger ribonucleic acid levels, promoter activity and secretion in the rat. Endocrinology 152, 1442-1447.

Muehlenbein, M.P., Watts, D.P., Whitten, P.L., 2004. Dominance rank and fecal testosterone levels in adult male chimpanzees (Pan troglodytes schweinfurthii) at Ngogo, Kibale National Park, Uganda. Am. J. Primatol. 64, 71-82.

Muller, M.N., 2002. Agonistic relations among Kanyawara chimpanzees. In: Boesch, C Hohmann, G., Marchant, L.F. (Eds.), Behavioural Diversity in Chimpanzees and Bonobos. Cambridge University Press, Cambridge, pp. 112-124.

Muller, M.N., Kahlenberg, S.M., Emery Thompson, M., Wrangham, R.W., 2007. Male coercion and the costs of promiscuous mating for female chimpanzees. Proc. R. Soc. Lond., B 274, 1009-1014.

Muller, M.N., Lipson, S.F., 2003. Diurnal patterns of urinary steroid excretion in wild chimpanzees. Am. J. Primatol. 60, 161-166.

Muller, M.N., Mitani, J.C., 2005. Conflict and cooperation in wild chimpanzees. Adv. Stud. Behav. 35, 275-331.

Muller, M.N., Wrangham, R.W., 2004a. Dominance, aggression and testosterone in wild chimpanzees: a test of the 'challenge hypothesis'. Anim. Behav. 67, 113-123.

Muller, M.N., Wrangham, R.W., 2004b. Dominance, cortisol and stress in wild chimpanzees (Pan troglodytes schweinfurthii). Behav. Ecol. Sociobiol. 55, 332-340.

Murray, C.M., Eberly, L.E., Pusey, A.E., 2006. Foraging strategies as a function of season and rank among wild female chimpanzees (Pan troglodytes). Behav. Ecol. 17, 1020-1028.

Newton-Fisher, N.E., 1999. The diet of chimpanzees in the Budongo Forest Reserve Uganda. Afr. J. Ecol. 37, 355-365.

Nielsen, J.H., 1982. Effects of growth hormone, prolactin, and placental lactogen on insulin content and release, and deoxyribonucleic acid synthesis in cultured pancreatic islets. Endocrinology 110, 600-606.

Norman, A.W., Litwack, G., 1997. HormonesSecond Edition. Academic Press, New York

Packer, C., 1979. Male dominance and reproductive behavior in Papio anubis. Anim. Behav. 27, 37-45.

Pasquali, R., Casimirri, F., De Iasio, R., Mesini, P., Boschi, S., Chierici, R., Flamia, R., Biscotti, M., Vicenatti, V., 1995. Insulin regulates testosterone and sex hormone-binding globulin concentrations in adult normal weight and obese men. J. Clin. Endocrinol Metab. 80, 654-658.

Plumptre, A., Cox, D., Mugume, S., 2003. The Status of Chimpanzees in Uganda. In: Albertine Rift Technical Report Series No. 2. Wildlife Conservation Society, New York.

Polonsky, K., Licinio-Paixao, J., Given, B., Pugh, W., Rue, P., Galloway, J., Karrison, T. Frank, B., 1986. Use of biosynthetic human C-peptide in the measurement of insulin secretion rates in normal volunteers and type I diabetic patients. J. Clin. Invest. 77, 98-105.

Pontzer, H., Wrangham, R.W., 2006. Ontogeny of ranging in wild chimpanzees. Int. J. Primatol. 27, 295-309.

Potts, K.B., 2008. Habitat heterogeneity on multiple spatial scales in Kibale National Park, Uganda: implications for chimpanzee population ecology and grouping patterns. PhD Dissertation. Yale University, New Haven, CT. 
Prager, D., Yamashita, S., Melmed, S., 1988. Insulin regulates prolactin secretion and messenger ribonucleic acid levels in pituitary cells. Endocrinology 122, 2946-2952.

Pusey, A.E., Oehlert, G.W., Williams, J., Goodall, J., 2005. Influence of ecological and social factors on body mass of wild chimpanzees. Int. J. Primatol. 26, 3-31.

Rubenstein, A., Clark, J., Melani, F., Steiner, D., 1969. Secretion of proinsulin C-peptide by pancreatic bold beta cells and its circulation in blood. Nature 224, 697-699.

Schwartz, M., Figlewicz, D., Baskin, D., Woods, S., Porte, D.J., 1992. Insulin in the brain: a hormonal regulator of energy balance. Endocr. Rev. 13, 387-414.

Sherry, D.S., Ellison, P.T., 2007. Potential applications of urinary C-peptide of insulin for comparative energetics research. Am. J. Phys. Anthropol. 133, 771-778.

Strack, A., Sebastian, R., Schwartz, M., Dallman, M., 1995. Glucocorticoids and insulin: reciprocal signals for energy balance. Am. J. Physiol. 268, R142-R149.

Tweheyo, M., Lye, K.A., 2003. Phenology of figs in Budongo Forest Uganda and its importance for the chimpanzee diet. Afr. J. Ecol. 41, 306-316.

Uehara, S., Nishida, T.,1987. Body weights of wild chimpanzees (Pan troglodytes schweinfurthii) of the Mahale Mountains National Park, Tanzania. Am. J. Phys. Anthropol. 72, 315-321.
Watts, D.P., Mitani, J.C., 2002. Hunting behavior of chimpanzees at Ngogo, Kibale National Park, Uganda. Int. J. Primatol. 23, 1-28.

Whitten, P.L., Brockman, D.K., Stavisky, R.C., 1998. Recent advances in noninvasive techniques to monitor hormone-behavior interactions. Yrbk. Phys. Anth. 41, $1-23$.

Willis, D., Mason, H., Gilling-Smith, C., Franks, S., 1996. Modulation by insulin of folliclestimulating hormone and luteinizing hormone actions in human granulosa cells of normal and polycystic ovaries. J. Clin. Endocrinol. Metabol. 81, 302-309.

Wilson, M.L., 2001. Imbalances of power: how chimpanzees respond to the threat of intergroup aggression. Ph.D. dissertation. Harvard University, Cambridge, MA.

Wrangham, R.W., 1975. The behavioural ecology of chimpanzees in Gombe National Park, Tanzania. Ph.D. dissertation. University of Cambridge, UK.

Wrangham, R.W., Chapman, C.A., Clark-Arcadi, A.P., Isabirye-Basuta, G., 1996. Social ecology of Kanyawara chimpanzees: implications for understanding the costs of great ape groups. In: McGrew, W.C., Marchant, L., Nishida, T. (Eds.), Great Ape Societies. Cambridge University Press, Cambridge, pp. 45-57. 